Saudi Journal of Humanities and Social Sciences

Abbreviated Key Title: Saudi J Humanities Soc Sci

ISSN 2415-6256 (Print) | ISSN 2415-6248 (Online)

Scholars Middle East Publishers, Dubai, United Arab Emirates

Journal homepage: https://saudijournals.com/sjhss

Original Research Article

\title{
Justice in Powering and Utilizing Land Rights against Foreign Investment
}

\author{
Margie Gladies Sopacua* \\ Faculty of Law, Pattimura University, Indonesia
}

DOI: $\underline{10.36348 / \mathrm{sjhss} .2020 . \mathrm{v} 05 \mathrm{i} 04.004}$

| Received: 30.03 .2020 | Accepted: 09.04.2020 | Published: 14.04.2020

*Corresponding author: Margie Gladies Sopacua

\section{Abstract}

Land is one of the most important natural resources, including land surface (ie water, forests, etc.) and natural resources contained in the land (ie mineral, coal and energy mining materials, etc.). In international relations, Indonesia surrenders to foreign investors the mining business of strategic mining materials that cannot yet be undertaken on its own due to technological and capital reasons, not based on the issue of equitable use of natural resources, but based on fair and civilized human principles. Fair because it receives mining results in a balanced, civilized manner because natural resources can be used conditionally to foreign citizens. Conversely, it is immoral when the weak economy and technology are controlled by those who control technology and are rich. The Indonesian state needs to use force and power to force foreign investors to carry out their obligations, as a form of fulfilling the self-justice of their people, not on a moral basis that foreigners who are already rich are treated better than their own nation. For this reason, justice in the sense of control and utilization of land rights in the State of Indonesia against foreign investment is no longer a moral issue but a matter of power and law.

Keywords: Foreign Investment, Justice, Land Rights, Powering, Utilizing.

Copyright @ 2020: This is an open-access article distributed under the terms of the Creative Commons Attribution license which permits unrestricted use, distribution, and reproduction in any medium for non-commercial use (NonCommercial, or CC-BY-NC) provided the original author and source are credited.

\section{INTRODUCTION}

The 1945 Constitution of the Republic of Indonesia in Article 33 paragraph (3) provides that "The earth and water and the natural wealth contained therein are controlled by the state and are used to the maximum prosperity of the people". This means that Indonesia's right to land is already the highest tenure right and covers all land in the state territory, which is shared land, is eternal and is the mother of other land tenure rights. Further regulations regarding land tenure are contained in Article 1 paragraph (1) through paragraph (3) of the Basic Agrarian Law.

Ronald Z. Titahelu on various occasions have stated statements that "Management of natural resources by the community has become a problem since the arrival of the state as an organization of power, and the existence of markets controlled by strong economic organizations that make natural resources under the control of the state and strong economic organizations, and then get rid of access of communities around natural resources to their own natural resources. The main target is the creation of high economic growth for the organization of state power on the one hand, and the accumulation of wealth in the hands of large business owners on the other [1]".
In 2014 Muhammad Ikhsan Rahmadiansyah revealed the reality that Indonesia's energy security had entered the vulnerable zone due to the failure to exercise sovereignty over oil and gas and mining resources. Oil and gas and mines which are supposed to be strategic resources are treated as limited commodities with minimal benefit value for people's welfare.

Foreign mining companies, especially China and India, enter control of small mines by financing local mining companies that have difficulty funding. "Without realizing it, we have become upstream resources for China and India. These two countries are very aggressive in seeking coal resources as a substitute for oil abroad, while they deliberately save oil and gas reserves and mines", said Singgih.

Referring to the British Petroleum Statistical Review data, Indonesia, which only has proven coal reserves of 4.3 billion tons or 0.5 percent of the total world coal reserves, is the main coal supplier for China, which has proven coal reserves of 114.5 billion tons or 13.9 equivalent percent of total world coal reserves. With an average production of 340 million tons per year, around 240 million tons are exported; proven 
reserves of Indonesian coal will be exhausted in 20 years. If this is left unchecked, Indonesia is threatened to become an importer of oil as well as coal.

In the oil and gas sector, control of oil and gas reserves by foreign companies is still dominant. Of the total 225 oil and gas blocks managed by non-Pertamina cooperation contract contractors, 120 blocks are operated by foreign companies, only 28 blocks are operated by national companies, and around 77 blocks are operated by foreign and local joint ventures.

The government through the Directorate General of Oil and Gas of the Ministry of Energy and Mineral Resources sets the target portion of operators by national companies to reach 50 percent by 2025 . Currently the national portion is only 25 percent, while 75 percent is controlled by foreigners.

The foreign domination in the oil and gas and mining sectors, with the domination of the working area that is widespread and spread from the Sabang region in the west to Papua in the east of the archipelago, makes the sovereignty of the state and nation vulnerable.

Foreign investment in many small islands that have the potential for tourism activities such as Cubadak Island in West Sumatra Province, Anambas Island, Raja Ampat Islands, Kei Islands in Southeast Maluku, Togean Islands in Tojo Una-Una Regency, Islands in Wakatobi Regency, Southeast Sulawesi.

The situation that has been stated above is a fact on the ground that occurs to the people of Indonesia. On the other hand, it can be seen the legal fact that the government issued Law Number 25 of 2007 concerning Investment, in its consideration in point c, regulates that "To accelerate national economic development and realize Indonesia's political and economic sovereignty, it is necessary to increase investment to process the potential of the economy to become a real economic power by using capital that comes from both domestic and foreign countries".

The definition stated above in relation to investment in general, the provisions of article 18 paragraph (1) and paragraph (2) of Law Number 25 Year 2007 provide facilities to investors who make investments. Provision of investment facilities can be given to investments that expand the business, or make new investments accompanied by various requirements that accompany it.

Article 20 of Law Number 25 Year 2007 does not require the form of a limited liability company for foreign investors while Article 21 of Law Number 25 Year 2007 provides facilities such as granting land rights. Article 22 of Law Number 25 Year 2007 regulates the ease of service and/or licensing of land rights can be granted and extended in advance at the same time and can be renewed at the request of investors, which include;

1. Entitlement rights can be granted in the amount of 95 (ninety-five) years by way of being granted and extended in advance at the same time for 60 (sixty) years and renewable for 35 (thirty-five) years;

2. Building Use Rights can be granted in the amount of 80 (eighty) years by way of being granted and extended in advance at the same time for 50 (fifty) years and renewable for 30 (thirty) years; and

3. The Right to Use can be granted in the amount of 70 (seventy) years by way of being granted and extended in advance at the same time for 45 (forty five) years and may be renewed for 25 (twentyfive) years.

In the case of handling Mineral and Coal mining, an Indonesian company is working together with a foreign company. The legal basis governing foreign investors working together with the national private sector in the field of mineral and coal mining is as follows;

1. Law Number 4 Year 2009 concerning Mineral and Coal Mining;

2. Law Number 25 Year 2007 concerning Investment;

3. Government Regulation Number 23 Year 2010 concerning Implementation of Mineral and Coal Mining Business Activities; and

4. Presidential Regulation Number 36 Year 2010 concerning List of Closed Business Fields and Open Business Fields with Requirements in the Field of Investment.

Prior to the issuance of Law Number 4 Year 2009 concerning Mining, Minerals and Coal, foreign companies often submitted their desire to have a $90 \%$ shareholding and sought a Coal Mining Entrepreneur Work Agreement (not a contract of work) in its operation, while Indonesian companies only received a minority quota. The Coal Mining Entrepreneur Work Agreement and Contract of Work based on the old Mining Law, replaced with a Mining Business License (IUP) according to Law Number 4 Year 2009. On the other hand there are provisions which are seen as the fact that there are restrictions for foreign investors to carry out business activities in the field of coal mining, as stipulated in Presidential Regulation Number 36 Year 2010 concerning List of Closed Business Fields and Open Business Fields with Requirements in the Fields Capital investment.

This regulation does not have restrictions on foreign investment in coal mining; therefore foreign investors may have $90 \%$ ownership. Then what must be done by foreign companies is to get permission from the Investment Coordinating Board (BKPM). Article 5 paragraph (2) of Law Number 25 Year 2007 concerning Investment regulates the provisions requiring foreign investors to make their companies in the form of limited liability companies (PT). For this reason, Indonesian 
companies and foreign investors must form a Limited Liability Company.

The reason for divestment for foreign investors, as stipulated in Article 112 of Law Number 4 Year 2009 concerning Minerals and Coal, is that after 5 (five) years of production, business entities holding mining business licenses whose shares are owned by foreigners are required to divest shares. The divestment is carried out by the Government, including regional governments, state-owned enterprises, regionallyowned business entities, or national private business entities. Furthermore Article 97 of Government Regulation No. 23 of 2010 concerning Implementation of Mineral and Coal Mining Business Activities regulates the magnitude of shares that must be divested, ie at least $20 \%$ (twenty percent) of shares owned by Indonesian participants. Therefore, although currently foreign investors are allowed to hold shares of $90 \%$, but 5 (five) years after producing, the foreign investor is obliged to divest shares to a maximum of $80 \%$.

In connection with copper and gold mining by Freeport MacMoran in Timika, which previously was a Contract of Work, it must be changed to a Mining Business License (IUPK), because based on Government Regulation Number 1 of 2017 Regarding the Fourth Amendment to Government Regulation Number 23 of 2010 concerning Implementation of Activities Mining, Mineral and Coal Businesses, then the Contract of Work holder can no longer export concentrates (minerals that have been processed but have not yet reached the refining stage. However, Freeoprt cannot pocket IUPK because it cannot fulfill 11 requirements[2] including building a smelter in the next 5 years, making an integrity pact, fulfilling the obligation to pay PNBP, mining permit status must be Clean and Clear $(\mathrm{CnC})$. Verification of mineral reserve data by the Indonesian Mineral Reserves Committee (KCMI) which must be included in the Work Draft and Budget (RKAB). Then next, the assessments are submitted to the government.

Philosophical perspectives regarding ontology are epistemologically obtained [3]. These facts show a number of material legal concepts namely about giving business authority, legal protection to the people of Indonesia, state sovereignty, overpowered by the state, controlled by the state, managed by the state, and social justice in participating world order based on freedom and eternal peace. The concept of the law is closely related to the legal epistemology of the power and authority of effort. Power is related to the right to determine and regulate. The authority to endeavor relates to "the activities of a person or certain party conducting business based on the granting of permission obtained from the government to carry out the business which in principle may not be carried out". Based on the explanation, the problem that will be discussed in this paper is how is justice in controlling and utilizing Indonesian land rights against foreign investment?

\section{RESEARCH METHOD}

Research is a process to find the rule of law, legal principles, and legal doctrines to address the legal issues at hand [4]. This type of research is normative juridical research is legal research conducted by examining library materials or secondary legal materials [5].

\section{DISCUSSION}

\section{Justice for Rights and Land against Foreign} Investment from the Legal Philosophy Side

Indonesia as a legal state based on Pancasila and aims to achieve a just and prosperous, spiritual and material society that is equitable, is not only tasked with maintaining order, but is broader than that. Because it is obliged to participate in all sectors of life and livelihood. Participating in the state in all sectors of life is to create a welfare state in creating a just and prosperous society, both spiritually and materially [6].

Ronald Titahelu argues that "thoughts about legal principles originating from Pancasila need to be developed [7]". This thinking is necessary because legal principles involve the study of law, knowledge of law and understanding scientific knowledge of law. Therefore, it is also referred to as the philosophy of law. The Relevance of Philosophy (Law) Pancasila is concerning the interests of Indonesian law over Indonesia itself as a Nation and State, which has sovereignty and power to regulate its natural resources to fulfill its interests.

The urgency of using the Philosophy (Law) Pancasila is that this philosophy needs to be the main guideline in placing Indonesia in and outgoing relationships.

The relevance of John Austin's theory departs from sovereignty and state power establishes binding laws. The urgency of the use of this theory is related to the use of the Philosophy (Law) Pancasila, specifically regarding the sovereignty of the people carried out by the state through granting permits and supervising and cracking down on requirements that are not fulfilled.

Land is the gift of God Almighty to the people of Indonesia, is one of the main sources for the survival and livelihood of the nation. Then the land is to be cultivated or used for the fulfillment of primary and real needs. In connection with that, the provision, designation, control, use and maintenance of it must be regulated so that legal certainty in its mastery and use is carried out as well as at the same time providing legal protection for the people, especially the peasant groups while maintaining the preservation of their ability to support sustainable development activities [8]. 
Apart from that land is also a very important State asset, besides that land also has a high economic value and is an item for investment business. Land can indirectly provide welfare to the people, what gives welfare is human activity on it which is realized in its use and utilization. The availability of a land for investment growers is already a basic prerequisite.

The land problem is an interesting problem to study all the time. This is evident from a comprehensive study of land policy in Asian countries. In Indonesia where a plurality of land laws takes place, the problem is increasingly complex because land has economic, social, cultural and political values. Of the various problems, what drives the government to intervene and regulate them is economic and political values. The economic value of land can be observed from the meaning of land as the most basic capital of various types of capital known in the economy [9].

Theory of Justice from David Hume. The relevance of David Hume's use of justice is based on his philosophy influenced by John Rawls, about the rights and obligations arising from contracts or agreements. Departing from the view of his lifetime, Hume saw that the British agreement with Scotland was very unbalanced for Scotland. Many parties are very attached to the liberal view of the dominance of the strong, Britain, to the weak, Scotland. Facing this condition, David Hume raised the issue of nationality, an issue which was outside the agreement between England and Scotland. David Hume wants integration of nationality as a moral component of justice theory [10]. The urgency of David Hume's theory of justice is closely related to the principal of Indonesia's sovereignty over natural resources, in this case regarding mining, if foreign investors do not fulfill their obligations.

\section{Justice in Controlling and Utilizing Land Rights against Foreign Investment}

Law No. 5 Year 1960 concerning Basic Regulations on Agrarian Principles or more popularly called the Basic Agrarian Law contains articles that are not always clear. The reach to provide answers to various problems that occur in the community is still low, for example related to the prohibition of ownership of private property by foreigners. The Basic Agrarian Law does not provide articles which can immediately be used to resolve legal issues. Scholten in this case said that something is imaginary if one thinks that the law has completely regulated everything, 4 legal regulations are incomplete and may not be complete [11].

Theoretical understanding of state power over natural resources (earth, water, space and natural wealth), sourced from the people known as the rights of the nation [12]. The state is seen as an organization that has the character of an institution of the general public, so that it is given the authority or power to regulate, manage, maintain and supervise the use of all potential natural resources in its territory intensively, but not as the owner because the owner is the Indonesian Nation[13].

The state's right to control over land originates from the Indonesian Nation's Right to land, which in essence is an assignment to carry out the duties of the nation's authority that contains public elements. The task of managing the entire land together is not possible to be carried out alone by the entire Indonesian Nation, so in its administration, the Indonesian Nation as the holder of the right and the bearer of the mandate, at the highest level carried out 58 Article 1 paragraph (3) Basic Agrarian Law, Article 2 paragraph (1) and paragraph (2) Basic Agrarian Law by the Republic of Indonesia as an organization of power for all people [14].

According to Boedi Harsono, the rights of the nation are the "highest tenure rights", in addition to other land tenure rights underneath [15]. Land tenure rights according to the Basic Agrarian Law are arranged in the following order:[16]

1. The rights of the Indonesian people (Article 1);

2. State's right to control over land (Article 2);

3. Customary rights of customary law communities (Article 3);

4. Individual rights (Article 16).

Furthermore, Notonagoro gave an understanding of the right to control the state not in the sense of possessing [17]. Likewise, according to A.P. Parlindungan[18], the right to control the state is one of the principles in the LoGA which is different from the principle of dominion in Agrarische Wet 1870 jo. Agrarisch Besluit 1870. The application of the principle of dominion for the benefit of colonial government, not for the benefit of the people. The assumption of the implementation of the principle of dominion, that according to the colonial government, the people who consisted of various ethnic groups in Indonesia had fully surrendered to the colonial government. While the right of state control is aimed at the greatest prosperity of the people which includes happiness, prosperity, and independence in the society and the rule of law of Indonesia, which is independent, sovereign, just, and prosperous

It is controlled by the state and to achieve the welfare of the people according to Bagir Manan [19], an independent Indonesian state is a welfare state as intended in the Preamble of the 1945 Constitution of the Republic of Indonesia.

The concept of the right to control the state in the legal considerations of the Constitutional Court ruling in the case of the Oil and Gas Law, the Electricity Law, and the Law on Natural Resources 
states that "The State's Right to Control" is not in the sense that the State has, but in the sense that the State has the right formulate policies (beleid), make arrangements (regelendaad), make arrangements (bestuurdaad), carry out management (beheerdaad), and supervise (toezichtthoundendaad)[20] in the field of Natural Resources.

The right to control the state over natural resources in the decision of the Constitutional Court (hereinafter referred to as the Constitutional Court), if it is associated with the goal of the greatest prosperity of the people, will give birth to the state's obligation to regulate:[21].

a) All forms of utilization (earth and water) and the results obtained (natural resources), must significantly increase the prosperity and welfare of the community;

b) Protect and guarantee all the rights of the people contained in or on the earth, water and certain natural resources that can be directly or directly enjoyed by the people;

c) Prevent all actions from any party that will cause the people do not have the opportunity or will lose their rights in enjoying natural resources.

The control over natural resources was then developed by Soepomo [22] as quoted in the consideration of Constitutional Court Decision Number 001/PUU-II/2003, 021/PUU-II/2003, and 022/PUUII/2003 (Constitutional Court Decision) which tested the Law Number 20 Year 2002 concerning Electricity states that the phrase "controlled by the state" provides the meaning to regulate and/or administer primarily to improve and consider the production of these natural resources. In addition, the notion of "controlled by the state" was also put forward by Mohammad Hatta [23] who formulated that the notion of "controlled by the state" that the state was not a businessman or entrepreneur, but rather said that state power was in making regulations for the smooth running of the economic path, the regulation also prohibits the use of weak people by people who have capital.

Based on the things that have been found, the authors conclude that in terms of being the holder of power over natural resources which includes earth, water, and natural wealth in it is the government. The government in this case is the government which is given authority in matters of regulating and also controlling or supervising the use and utilization of natural resources managed by certain people or institutions.

The state is the main actor in the fulfillment of the rights of its citizens, including the fulfillment of a sense of security from crime and social conflict [24] In international relations, Indonesia surrenders to foreign investors the mining business of strategic mining materials that cannot yet be undertaken on its own due to technological and capital reasons, not based on the issue of equitable use of natural resources, but based on fair and civilized human principles. Fair because it receives mining results in a balanced, civilized manner because natural resources can be used conditionally to foreign citizens. Conversely, it is immoral when the weak economy and technology are controlled by those who control technology and are rich.

International treaties should bring good for every country that makes them [25] Even though there are not many Indonesian legal scientists who explain the study of law, legal knowledge, and legal knowledge of Pancasila, an effort to develop the knowledge of Pancasila law must be carried out by Indonesian scientists. In this writing the authors offer legal principles including the following;

1. Indonesian people are more entitled to natural resources on Indonesian earth; because the underlying law is natural wealth is a gift from God Almighty. Therefore, Indonesia is more entitled to natural resources on Indonesian soil;

2. The use and utilization of natural resources is conducted in a fair and civilized manner so that foreigners too, based on agreements and moral and civilized behavior may use it through permits and conditions from the Indonesian people through the government and the approval of state higher institutions that represent the people's rights (fulfill the precepts to the point 3 and 4);

3. The principle of social justice law for all Indonesian people. Distribution of $10 \%$ - $20 \%$ for Indonesia, and $90 \%-80 \%$ for foreigners as regulated by the law, means the law does not protect the entire nation and the whole of Indonesia's blood.

Even though John Austin clearly distinguishes orders from the law, where law is broader than the word command, and this is the main key to understanding the law, John Austin can still accept morals as considerations to become law through the process of judging by judges [26]. In international relations which place the state as the subject of special international law in the character of private law, it is possible for settlement to be done through International Arbitration. But as a subject of international law with a public character, John Austin's view is very extreme supported by Thomas Nagel [27].

For Nagel the power of a sovereign state is to fulfill its own interests [27]. Here the moral meaning for Thomas Nagel is for the benefit of its own citizens. This means that the power of a sovereign state is aimed at other countries or also against other citizens. For him, "respect for other people's autonomy and is seen as an appreciation of the human rights of their members, rather than respecting equality with others [27]". As noted above, the urgency of David Hume's theory of 
justice is closely related to the principle of Indonesia's sovereignty over natural resources, it can be argued that based on the principle of fair and civilized humanitarian law, civilized Indonesian nationality is aligned and integrated into bonds or work agreements with foreign parties, not in a position of private and unbalanced relations, but on the contrary in an equal and balanced relationship (equivalent). In this connection the yield sharing of $10 \%$ or $20 \%$ for Indonesia and $90 \%-80 \%$ for foreign investors, must be changed to $50 \%-50 \%$.

Rights are something that is inherent in every human being, and rights can be applied in every scope of life [28]. The morality of civilized humans is still applied to the balanced and parallel division. Mastery and mining with unbalanced results, coupled with the non-fulfillment of mining permit conditions, results in the need to use justice with power and strength not for moral reasons. The argument is that foreign investors are rich. Many developing countries have poor people. It is not fair to equalize the poor and the rich from two different countries. Therefore, power and power need to be used to obtain justice.

Based on the understanding stated above, it can be concluded that justice in the sense of control and utilization of land rights in the Republic of Indonesia for foreign investment or foreign investors is not a moral issue but an issue of power and law.

\section{CONCLUSION}

In international relations, Indonesia surrenders to foreign investors the mining business of strategic mining materials that cannot yet be undertaken on its own due to technological and capital reasons, not based on the issue of equitable use of natural resources, but based on fair and civilized human principles. Mastery and mining with unbalanced results, coupled with the non-fulfillment of mining permit conditions, results in the need to use justice with power and strength not for moral reasons. Therefore, power and power need to be used to obtain justice. For this reason, justice in controlling and utilizing land rights in Indonesia against foreign investment is not a moral issue but a matter of power and law.

\section{REFERENCES}

1. Ronald, Z. (2010). Titahelu 'Authority of Indigenous Peoples or Local Communities in Natural Resource Management: Overview from the Legal, Human Rights and Economic Perspectives. Socio-Culture, Paper presented at a Seminar held by the National Commission on Human Rights in collaboration with the Representative Office of National Commission on Human Rights in Maluku held in Ambon in October 2010

2. Director General of Mineral and Coal of the Ministry of Energy and Mineral Resources, Bambang Gatot Aryono, at the Coffee Morning event at the Office of the Director General of
Mineral and Coal, Jakarta, February 2, 2017, see http://finance.detik.com/energi/3411773/freeportaccessed 27 December 2019

3. Gray, P. N. (2005). Ontology and Epistemology in Legal Knowledge Engineering. In ICAIL Workshop on Legal Ontologies and Artificial Intelligence Techniques (LOAIT).

4. Peter, M. M. (2006). Penelitian Hukum (Legal Research), Kencana Prenada media Group, Jakarta, 35

5. Soerjono, S. (2012). Metode Penelitian Hukum (Legal Research Method), Jakarta, 13

6. Buchsan, M.(1995). Pokok Pokok Hukum Administrasi Negara (Principal Law of State Administration), Alumni, Bandung, 15

7. Titahelu, J. A., Irwansyah, I., Awaludin, H., \& Ashri, M. (2015). Strengthening Pela-Gandong Alliance Based on John Rawls' Theory of Justice. Hasanuddin Law Review, 1(3), 417-429.

8. Rokilah, R., \& Mukaromah, M. (2018). Pemilikan Hak Atas Tanah Bagi Warga Negara Asing. Ajudikasi: Jurnal Ilmu Hukum, 2(2), 137150.

9. Jefrey, W.(1999). Modal Berpindah, Modal Berkuasa, Mobilitas Unvestasi dan Polotik di Indonesia (Moving Capital, Ruling Capital, Investment Mobility and Politics in Indonesia), Fajar Harapan, Jakarta, 19

10. Ainslie, D. C. (1995). The problem of the national self in Hume's theory of justice. Hume Studies, 21(2), 289-313.

11. Sudikno, M. (1991). Mengenal Hukum: Suatu Pengantar (Know the Law: An Introduction), Yogyakarta: Liberty, 104

12. Sumardjono, M. S. (2008). Tanah dalam perspektif hak ekonomi, sosial, dan budaya. Penerbit Buku Kompas.

13. Article 33 paragraph (3) of the 1945 Constitution of the Republic of Indonesia

14. Basic Agrarian Law, Article 2 paragraph (1)

15. Boedi, H. Hukum Agraria Indonesia: Sejarah Pembentukan Undang-Undang Pokok Agraria, Isi dan Pelaksanaannya (Indonesian Agrarian Law: History of the Establishment of the Basic Agrarian Law, Content and Implementation), Jakarta, 229

16. Boedi, H. Hukum Agraria Indonesia: Sejarah Pembentukan Undang-Undang Pokok Agraria, Isi dan Pelaksanaannya (Indonesian Agrarian Law: History of the Establishment of the Basic Agrarian Law, Content and Implementation), Jakarta, 264

17. Notonagoro.(1984). Politik Hukum dan Pembangunan Agraria di Indonesia (Legal Politic and Agrarian Development in Indonesia), Jakarta: Bina Aksara.

18. Noor, A. (2006). Konsep hak milik atas tanah bagi bangsa Indonesia ditinjau dari ajaran hak asasi manusia. Mandar Maju.

19. Manan, B., Mashudi, \& Magnar, K. (1995). Pertumbuhan dan Perkembangan Konstitusi Suatu Negara. Mandar Maju. 
20. Decision of the Constitutional Court No. 2122/PUU-V/2007 concerning the Investment Law Jo. Decision No. 01-02-022/PUU-I/2003.

21. Firman, M.(2010). Karakter Kebijakan Hukum Pertanahan Era Orde Baru dan Era Reformasi (Character of Land Legal Policy in the New Order Era and Reform Era), Semarang, Badan Penerbit Undip, 71-72

22. Doly, D. (2017). Kewenangan Negara Dalam Penguasaan Tanah: Redistribusi Tanah Untuk Rakyat (The Authority Of The State In Land Tenure: Redistribution Of Land To The People). Negara Hukum: Membangun Hukum untuk Keadilan dan Kesejahteraan, 8(2), 195-214.

23. Mohammad, H.(1977). Penjabaran Pasal 33 Undang-Undang Dasar 1945 (Elucidation of Article 33 of the 1945 Constitution), Jakarta, Mutiara, 28
24. Birkah, L., \& Kadarudin.(2012). Pengantar Hukum Internasional (Introduction to International Law), Makassar: Pustaka Pena Press, 39

25. Birkah, L., \& Kadarudin.(2012). Hukum Perjanjian Internasional (International Treaty Law), Makassar: Pustaka Pena Press, 51

26. John, A. (1832). The Province of Jurisprudence Determind, John Murray, Albe Marle Street, London, 6

27. Thomas, N. (2005). The Problem of Global Justice in Philosophy and Public Affairs, No. 2, Blackwell Publishing, Inc.

28. Kadarudin, K. (2015). Legal Guarantees and Inconsistency of State Recognition to the Right of Religion/Belief in Indonesia. Hasanuddin Law Review, 1(1), 1-16. 